\title{
Self-Concept and Aggression among Institutionalised Orphans of Kashmir
}

\author{
Rakshanda Ahad $^{1 *}$, Shabnum Ara ${ }^{1}$, Shawkat Ahmad Shah ${ }^{2}$
}

\section{ABSTRACT}

The present study was undertaken to examine the Self-Concept and Aggression among adolescent orphans of Kashmir. The sample consisted of 88 adolescent orphans (47males \& 41 females) taken from different orphanages of Kashmir. The age of the sample group ranged from 15 to 17 years with mean age of 16 years. Purposive sampling technique was used for the research purpose. Self-concept Questionnaire (SCQ) by Raj Kumar Saraswat (1984) and Aggression Scale (A-Scale) by Pal and Naqvi (1983) was used. Results revealed that most of these adolescent orphans have above average level of self-concept and majority of them were found to have moderate to high level of aggression. The findings of the present study also reveal that there is no significant correlation in self-concept and its four dimensions i.e. physical selfconcept, social self-concept, moral self-concept \& intellectual self-concept with aggression. However, temperamental self-concept dimension has significant negative correlation with aggression and educational self-concept dimension has significant positive correlation with aggression. Results further reveal significant mean difference in self-concept of male \& female adolescent orphans. However, no significant mean difference was found in the aggression level of male and female adolescent orphans.

Keywords: Self-Concept, Aggression, Institutionalised Orphans, Kashmir

Self-concept refers to people's characteristic ideas about who they are and what they are like. Thinking about oneself is an unavoidable human activity; the self is the centre of each person's social universe. The term self-concept is a general term used to refer, how someone thinks about or perceives themselves. It is central theme around which a large number of major aspects of personality are organized. One of the psychologists who first wrote about the self-concept was William James a psychologist in the late $19^{\text {th }}$ century. James distinguished between I and ME. The I is the part of self that is actively perceiving and thinking. The ME is the part of self that becomes an object of person's thoughts and perceptions. The self-concept relates primarily to ME. "Self-concept is a person's perceptions of himself formed through experience with and

\footnotetext{
${ }^{1}$ Research scholar, Department of Psychology, University of Kashmir, Srinagar

${ }^{2}$ Associate Professor, Department of Psychology, University of Kashmir, Srinagar

*Responding Author

(C) 2016 I R Ahad, S Ara, S Shah; licensee IJIP. This is an Open Access Research distributed under the terms of the Creative Commons Attribution License (http://creativecommons.org/licenses/by/2.0), which permits unrestricted use, distribution, and reproduction in any Medium, provided the original work is properly cited.
} 


\section{Self-Concept and Aggression among Institutionalised Orphans of Kashmir}

interpretations of the environment. These perceptions are influenced by a number of factors such as evaluations of significant others, reinforcements, and attributions of behavior" (Shavelson et al., 1976). Self-concept "is the set of perceptions or reference points that the subject has about himself: the set of characteristics, attributes, qualities and deficiencies, capacities and limits, values and relationships that the subject knows to be descriptive of himself and which he perceives as data concerning his identity" (Sanchez and Roda, 2007). "Self-concept is the product of one's reflectivity; it is concept of the individual of himself as a physical, social and moral and existing being. The self-concept is sum total of the individual's thoughts and feelings about him or herself as an object” (John, 2000). According to Purkey (1988): “Self-concept may be defined as the totality of a complex, organized, and dynamic system of learned beliefs, attitudes and opinions that each person holds to be true about his or her personal existence". According to Hamachek as cited by Shafique (2002) "Self-concept refers to that particular cluster of ideas and attitudes we have about ourselves at any given moment”. The self concept has also been described as a nucleus of personality. As Cattel (1957) referred to self-concept as the "key stone of personality". Thus self-concept appears to be a comprehensive and exhaustive area which can represent the personality at large. Recognizing its broader coverage than any other trait of personality self-concept has been chosen as one of the possible dimensions which give direction to the whole life as Bracken (1992) puts it "Self-concept is a multidimensional and context-dependent learned behavioral pattern that reflects an individual's evaluation of past behaviors and experiences, influences an individual's current behaviors, and predicts an individual's future behaviors".

\section{Model of Self-Concept:}

Shavelson, Hubner and Stanton (1976) proposed multifaceted and hierarchical model of Selfconcept. It was recommended that the general self-concept is composed of four self-concept domains: the academic self-concept, social self-concept, emotional self-concept and physical self-concept. The academic self-concept can be divided further into second order specific subject self-concepts like English, History, Mathematics, and Science etc. which can explain learner achievement in each subject. Social self-concept can be divided into peer self-concept and significant others self-concept. Emotional self-concept will refer to specific emotional states such as anxiety, love, happiness, depression, and anger. Finally, the physical self-concept consist of physical ability and physical appearance self-concepts. The overall concept of self appears to be divided into at least three segregated but partially related self-concepts i.e. academics, emotional, and nonacademic. Recent research has recognized artistic ability as a separate entity of selfconcept. These self-concepts are themselves made up of more specific, separate conceptions of the self, such as of physical ability, appearance, relations with peers, and relations with parents. These conceptions are based on many experiences and measures such as: sports performance; assessment of body, skin, or hair; friendships; artistic abilities; contributions to community groups etc. (Myburgh et al., 1999). Adolescents seem to have separate, precise self-concepts, but these may not essentially integrate into an overall self-concept. Perhaps the young adolescents, 


\section{Self-Concept and Aggression among Institutionalised Orphans of Kashmir}

facing the challenges of different academic subjects in school and the "life task" of forming individuality, try to incorporate across their many "selves" to achieve that individuality.

Continued research proved that the hierarchy proposed by Shavelson et al. (1976) was weak, and also that the particular facets of self-concept (which include social, academic, physical, and emotional) were highly differentiated. Thus findings finally led to the Marsh-Shavelson revision (e.g., Marsh and Shavelon, 1985) of the original model. As a result, the multidimensional nature of the Shavelson et al. (1976) model became the original theory's greatest legacy, as it proved basic in the development of innovative self-concept measurement instruments that in turn led to revisions in self-concept theory (O’Mara, 2003). The growing body of research indicated that self-concept is relatively undifferentiated for early adolescents it becomes increasingly multidimensional during adolescence. Marsh and Ayotte (2003) developed a differential distinctiveness hypothesis which proposes that while there is a differentiation of disparate areas of self-concept with age, there is an increasing integration of closely associated self-concept areas.

\section{Development of Self-Concept:}

Self-concept originates in the early months of life and is modeled and remodeled through repeated experiences, particularly with significant others, because the self-concept is learned, and no one is ever born with a self-concept (Purkey, 1988). There are three types of factors that affect the development of self concept; chronological, external and internal. Chronological development of self concept has three segments: childhood, adolescence and adulthood. The years from birth to age 18 are considered as formative years. During this time, the main factors determining the formation of the self-concept of an individual are the environment as well as people with whom the individual live play a very crucial role in the molding of the self concept. These people are called the significant others and they include parents, teachers, peers and sibling. Johnson Pynn et al. (2003) claim that people describe a given individual in terms of various personality traits and when these traits are consistently applied, the person often accepts them as descriptions of him or her. According to UNICEF (2006), if parents praise and love a child, if playmates respect and give attention to the individual, he forms a picture of himself as a desirable person and hence develops a positive self-concept. On the other hand, if parents and peer reject and criticize the individual and are indifferent, this leads to a derogatory self-picture resulting in inferiority feelings. The specific internal factors that affect self-concept are fear, doubt, and anxiety. Factors like low love of self, and lack of positive opinion about self, a lot of criticism and judgment, blaming yourself and having self-doubt contribute to a negative selfconcept. In this, the person experiences uncertainty and lack of self-confidence in his capabilities which results in general anxiety in situation. These negative feelings affect his actions and other's reactions, validating negative feelings about self. In these situations, the adolescent's personal and social conduct loses its balance (Jerajani, 2006) and therefore develops negative self-concept. 


\section{Self-Concept and Aggression among Institutionalised Orphans of Kashmir}

\section{Aggression:}

Recently, not only researchers but also professionals of Psychology and allied disciplines have focused on aggressive behavior in adolescence (Dodge, Coie, \& Lynam, 2006). The special attention paid to aggressive behavior is due to its high prevalence during that developmental stage (Diaz-Aguado, Martinez- Arias, \& Martin-Seoane, 2004; Ingles et al., 2008) and the negative consequences related to such behavior.

Aggression is behavior that is intended to produce harm or damage to someone or to something functioning as a substitute for that personal target. Intention and harm doing are key attributes in defining aggressive behavior, which may be physical, verbal or symbolic in form. Human aggression is an acquired behavior. However, individual differences in aggression appear during infancy and early childhood, as manifested in temperament and rough-and-tumble play. There is growing evidence of an inherited predisposition to aggression, determined from longitudinal studies of twins reared apart and of adopted children, whereby a person's aggressive behavior as an adult has been found to be more concordant with biological parents than adoptive parents. Nonetheless, genetic predispositions are just that-something to which the child's early learning experiences will give shape. Whether the predisposition is potentiated, exacerbated, buffered or neutralized is a function of socialization process.

The learning of aggression occurs primarily in family relationships, peers and environmental exposure. The process of acquisition most generally involves observational learning through exposure to aggressive behavior and to values supporting enacted aggression, including reinforcement and punishment contingencies. This is contextually driven as children raised in an environment replete with deprivation, frustration, victimization, and instability will have many opportunities to develop aggression and to not learn inhibitory control. The rewards for aggression tend to be in the present; in contrast, the rewards for aggression control tend to be in future. When someone discounts or devalues the future, aggression is more likely.

The family and home environment furnish the central opportunities for the development of aggression. Family interaction patterns, involving siblings as well as parents or caregivers, provide model of aggressive behavior and direct opportunities to learn how aggression functions in meeting needs. In observing how parents respond to distress or conflict, children learn aggression as a proponent response to aversive events. Parents or caretakers behavior, such as occurs in a disciplinary confrontation, may model coercion as a way of achieving compliance. Displays of coercive power in the form of physical punitiveness and verbal abuse, as opposed to reasoning and firm discipline motivated by love, will breed aggression. Moreover, when the parent or caretaker is rejecting of the child and fails to provide security, warmth, and affection, the child learns that mistreatment is normative. There is considerable evidence that children raised by parents or caretaker who is physically punitive and emotionally rejecting are more likely to have behaviour problem. Insecurity and impulsive aggression easily develop from harsh, erratic, and inept discipline during formative years. The observational learning process 


\section{Self-Concept and Aggression among Institutionalised Orphans of Kashmir}

that applies to the acquisition of aggression from witnessing aggression enacted by parents, siblings, and peers also applies to the modeling that occurs in media exposure. The process of observational learning, whether through real or fictional models, can be understood in terms of development of cognitive scripts for aggression-that is, mental programs for processing information that are conducive to aggressive behavior. People encode information about environment-behaviour transaction in the form of scripts that become guides for behavior in situations resembling those of encoding. Cognitive scripts develop through paying attention to, encoding, and retaining in memory the event-response-outcome sequences. The script then becomes a guide for behavior and social problem solving. It can be rehearsed, reinforced, and elaborated over time as its enactment generates consequences. Aggressive scripts, which are activated in conjunction with situational cues, can be highly automatized in their operation. Learned scripts are resistant to change. As development proceeds from childhood to adulthood, subsets of learned scripts can be abstracted to more general scripts that function as personal rules for aggression as social behavior.

Freud believed the death instinct sometimes gets turned outward, and then we hurt and offend others and go to war (the opposite of suicide). Rochlin (1973), another psychoanalyst, believes Aggression is our way of recovering lost pride. Given the common human need to feel powerful and to think highly of ourselves, any threat to our self-esteem is taken as a hostile attack. When our pride is hurt, we often attempt to restore our status and self-esteem by hurting the person who offended us. Toch (1969) found that $40 \%$ of aggressive prisoners had been insecure and needed some "victory" to prove they were something special. Presumably the unpleasant memories maintain the hostility which, in turn, fuels more aggressive fantasies and distrust of others. On the other hand, research has consistently shown that people who are frequently aggressive have a very limited ability to think of different or more creative ways of handling the angering situation or person (Singer, 1984).

\section{Relationship between Self-concept and aggressive behavior among adolescents:}

Adolescence is a developmental stage characterized by important physical, cognitive and social changes. In some cases, those changes can contribute to the emergence of externalizing problems, such as aggressive behavior to peers (Estevez, Murgui, Musitu, \& Moreno, 2008a; Verona, Javdani, \& Sprague, 2011). However, changes during adolescence have not only influence on adolescent's social behavior, but also on their way of perceiving themselves, that is, in their self-concept (Gonzalez-Pienda, Nuñez, Gonzalez- Pumariega, \& Garcia, 1997). Both variables, aggressive behavior and self-concept, are considered as key factors for personal, social and academic adjustment for adolescents (Estevez, Musitu, \& Herrero, 2005; Marcus, 2007; Marsh, Craven, \& McInerney, 2003; Pastor, Balaguer, \& Garcia-Merita, 2006). There are numerous studies focusing on the relationship between self-concept and aggressive behavior in adolescence (Dodge et al., 2006). Studies highlighted the existence of a significant relationship between self-concept domains and aggressive behavior. Marsh, Parada and Ayotte (2004) found, in a sample of 903 Canadian students of 7th and 8th grade (12-14 years old), that aggressive 


\section{Self-Concept and Aggression among Institutionalised Orphans of Kashmir}

behavior was significant and negatively related to physical, family, academic, social and emotional self concepts. Similar results were obtained by Hay (2000), who analyzed the scores on SDQ-II domains by sex in a sample of aggressive adolescents. This author found that those males with aggressive behaviors showed a lower self-concept in family and academic domains and also in self-esteem, while females showed low scores in the same domains as males and also did in those referred to physical, social and emotional self-concept. Garaigordobil et al. (2003) found that aggressive interactions were significant and negatively related with academic and family self-concepts, whereas no significant relations were found regarding social self-concept in a sample of adolescents. Such results were similar to those informed by Estevez, Martinez and Musitu (2006), who used the Self-esteem Multidimensional Scale to state that those adolescents who behave aggressively with their peers showed lower scores in family and academic selfconcept, and higher scores in social and emotional self-concepts, when compared with their nonaggressive counterparts. Taking into account previous research findings, it is can be concluded that aggressive behavior has negative relationship with self-concept in both sexes.

\section{PURPOSE OF THE STUDY:}

Self-concept has an important place in a person's life especially in adolescence. During this period, there are various factors having effect on the self. Among these factors, socio-economic conditions (Bilgin, 2001), working in the streets (Arnas, 2004), adolescent's physical appearance (Phillips and Hill, 1998), their perception of their parents (Chamberlin, and Naijian, 2009), physiology (Song et al., 2007), friend relationships (Büyükşahin Çevik, 2007) and orphanage (Avdeeva, 2009) can be counted. More importantly among these factors living in an orphanage may have negative effects on self-concept of adolescences through affecting all developmental areas of these adolescents (Cebe 2005). Being brought up by an institution can affect children's development in a negative way (Sloutsky, 1997; Garland, Hough, McCabe, Yeh, Wood and Aarons, 2001; Üstüner, Erol, Şimşek, 2005; Jacobi, 2009). Studies show that adolescences living in orphanage have negative effects on their psychological health (Şimşek and Erol, 2004), social development (Tharp-Taylor, 2003; Pantıukhına, 2009; Shakhmanova, 2010), cognitive development (McCall, 1996; Sloutsky, 1997; MacLean, 2003), level of loneliness (Aral et al., 2006) and anxiety level (Gürsoy and Yıldız Bıçakçı, 2005). Studies also show that adolescences living in orphanages have low self-concept level. Aral, Gürsoy and Yıldız Bıçakçı, (2005) have determined that adolescents living in orphanage have less self-design level. Individuals with adversely affected self concept may be estranged from the society and the social relationships may be weakened. In time, said adolescents start to see themselves differently from the society which has negative impact on their psychological wellbeing. Anna Freud concluded from several case studies that institutionalized children are doomed to fail psychologically because of maternal deprivation. This was despite good physical and social care. Another psychoanalytically trained psychiatrist, John Bowlby also reported that maternal - deprivation was the central issue, causing psychological damage to orphanage children. Goodwin argues that any amount of orphanage experience is harmful; the damage is greatest during first year of life and increases dramatically with length of stay in an institution (Goodwin, D.K. 1984). It has also 


\section{Self-Concept and Aggression among Institutionalised Orphans of Kashmir}

been observed that in an orphanage setting children's emotional and behavioural status worsens and even in well run institutions children develop a range of negative behaviours, including aggression and indiscriminate affection towards adults (Tizard.B \& Rees .J,1996). Since, selfconcept and aggression are important variables that provide significant information regarding mental health of this target population. This therefore needs to be studied extensively which will further influence mental health policies relevant to them. Also the available literature on selfconcept and aggression has revealed that there are only few studies conducted so far to relate these variables especially among orphans. Keeping the above facts in view the investigators felt the need for carrying out the study of self-concept and aggression among adolescent orphans. Hence a study entitled "Self-concept and Aggression among Adolescent Orphans of Kashmir" was formulated with following objectives:

- To assess Self-concept, Aggression among adolescent orphans.

- To examine the relationship of Self-concept and its facets with aggression.

- To compare Self-concept and aggression among adolescent orphans with respect to gender.

\section{Hypothesis:}

On the basis of above objectives, the following hypotheses have been formulated:

Ho1: There is no significant role of Self-concept in determining the aggression among adolescent orphans.

Ho2: There is no significant difference in the Self-concept of male and female adolescent orphans.

Ho3: There is no significant difference in aggression of male and female adolescent orphans.

\section{METHODOLOGY:}

\section{Participants:}

A Sample of 88 adolescent orphans (47 males \& 41females) was taken from three orphanages of Kashmir and the sample was purely purposive in nature. The age of participant group ranges from 15 to 17 years with mean age of 16 years.

\section{Measures:}

Self Concept Questionnaire (SCQ) developed and standardized by Raj Kumar Saraswat (1984) was used for the assessment of self-concept. This questionnaire consists of 48 items distributed among six dimensions i.e. physical self-concept, social self-concept, temperamental self-concept, educational self-concept, moral self-concept and intellectual self-concept. Each response is rated on 5-point scale ranging from a score of 5 to most acceptable and 1 to least acceptable description of individual's self-concept. The summated score of all the 48 items provide the total self concept-score of an individual. A high score on this inventory indicates a higher selfconcept, while a low score shows low self-concept. The author has reported the scale as reliable and valid. The test-retest reliability of the inventory was found to be .91 for the total self-concept measure. A reliability coefficient of its various dimensions varies from .67 to .88. 
Aggression Scale (A-Scale) by Roma Pal and Tasneem Naqvi (1983) is based on the Frustration Scale by Chauhan and Tiwari (1971). The Scale consists of 30 items each item has to be graded on a five point scale. The correlation coefficient of the Scale is 0.82 indicating the high reliability of the Scale. The validity coefficient of the Scale is 0.74 showing its high validity.

\section{Procedure:}

The subjects were approached personally in these orphanages and instructed to give their responses on a questionnaire booklet. Assurance of confidentiality was given to the respondents to boost their motivation and reduce bias. After motivating the respondents the questionnaires were distributed and necessary help was provided by the researchers where ever required.

\section{Statistical Analysis:}

The analysis of data was carried out by using appropriate statistical tools. In order to find the differences between the groups t-test was used. Pearson's product Moment Correlation was used to determine the relationship between self-concept and aggression of adolescent orphans.

\section{RESULTS:}

Table1: Frequency distribution of self-concept and aggression among adolescent orphans.

\begin{tabular}{|l|l|l|}
\hline Self-concept & Frequency & Percentage \\
\hline Level & 0 & $0 \%$ \\
\hline Below Average & 0 & $0 \%$ \\
\hline Average & 88 & $100 \%$ \\
\hline Above Average & \multicolumn{2}{|l|}{} \\
\hline \hline Aggression & 18 & $20.45 \%$ \\
\hline Low & 37 & $42.05 \%$ \\
\hline Moderate & 33 & $37.5 \%$ \\
\hline High & & \\
\hline
\end{tabular}

The perusal of data fromTable- 1 reveals that all the adolescent orphans possess above average level of self-concept. It also reveals that $20.45 \%$ of adolescent orphans have low level of aggression, $42.05 \%$ have moderate level of aggression and $37.5 \%$ have high level of aggression. 
Table2: Correlation between Self-Concept, its dimensions and Aggression.

\begin{tabular}{|c|c|}
\hline Physical Self-Concept & \\
\hline Aggression & \multirow{3}{*}{$\begin{array}{l}r=.004 \\
r=.120\end{array}$} \\
\hline Social Self-Concept & \\
\hline Aggression & \\
\hline Temperamental Self-Concept & \multirow[b]{2}{*}{$\mathrm{r}=-.220 *$} \\
\hline Aggression & \\
\hline Educational Self-Concept & \multirow[b]{2}{*}{$\mathrm{r}=.234 *$} \\
\hline Aggression & \\
\hline Moral Self-Concept & \multirow[b]{2}{*}{$\mathrm{r}=.046$} \\
\hline Aggression & \\
\hline Intellectual Self-Concept & \multirow[b]{2}{*}{$\mathrm{r}=.134$} \\
\hline Aggression & \\
\hline Overall Self-Concept & \multirow{2}{*}{$\mathrm{r}=.095$} \\
\hline Aggression & \\
\hline
\end{tabular}

*correlation significant at 0.05 level

The perusal of data from Table-2 reveals that there is no significant correlation between four facets of Self-Concept i.e. Physical Self-Concept, Social Self-Concept, Moral Self-Concept, Intellectual Self-Concept and aggression while as significant negative correlation was found between Temperamental Self-Concept dimension and Aggression and significant positive correlation was found between Educational Self-Concept dimension and Aggression. It also reveals that there is no significant correlation between Overall Self-Concept and Aggression. Thus the null hypothesis Ho1 stands accepted.

Table3: Comparison of mean scores of Self-Concept (facet wise \& overall) and Aggression between male and female adolescent orphans.

\begin{tabular}{|c|c|c|c|c|c|c|}
\hline Variable & Group & $\mathbf{N}$ & Mean & $\begin{array}{l}\text { Std } \\
\text { Deviation }\end{array}$ & df & t-value \\
\hline \multirow{2}{*}{$\begin{array}{l}\text { Physical } \\
\text { Self-Concept }\end{array}$} & Male & 47 & 32.2979 & 3.52577 & \multirow[t]{2}{*}{86} & \multirow[t]{2}{*}{$5.384^{* *}$} \\
\hline & Female & 41 & 28.0000 & 3.96232 & & \\
\hline \multirow{2}{*}{$\begin{array}{l}\text { Social } \\
\text { Self-Concept }\end{array}$} & Male & 47 & 31.0851 & 3.00601 & \multirow[t]{2}{*}{86} & \multirow[t]{2}{*}{$1.029^{\mathrm{NS}}$} \\
\hline & Female & 41 & 30.4390 & 2.85525 & & \\
\hline \multirow{2}{*}{$\begin{array}{l}\text { Temperamental } \\
\text { Self-Concept }\end{array}$} & Male & 47 & 29.8298 & 4.02880 & \multirow[t]{2}{*}{86} & \multirow[t]{2}{*}{$-0.121^{\mathrm{NS}}$} \\
\hline & Female & 41 & 29.9268 & 3.40874 & & \\
\hline \multirow{2}{*}{$\begin{array}{l}\text { Educational Self- } \\
\text { Concept }\end{array}$} & Male & 47 & 33.2766 & 4.24624 & \multirow[t]{2}{*}{86} & \multirow[t]{2}{*}{$2.592^{* *}$} \\
\hline & Female & 41 & 31.1707 & 3.21638 & & \\
\hline \multirow{2}{*}{$\begin{array}{l}\text { Moral } \\
\text { Self-Concept }\end{array}$} & Male & 47 & 34.0426 & 2.43129 & \multirow[t]{2}{*}{86} & \multirow[t]{2}{*}{$-0.855^{\mathrm{NS}}$} \\
\hline & Female & 41 & 34.5122 & 2.72141 & & \\
\hline \multirow{2}{*}{$\begin{array}{l}\text { Intellectual Self- } \\
\text { Concept }\end{array}$} & Male & 47 & 27.4255 & 4.74912 & \multirow[t]{2}{*}{86} & \multirow[t]{2}{*}{$2.845^{* *}$} \\
\hline & Female & 41 & 24.9268 & 3.22017 & & \\
\hline \multirow{2}{*}{$\begin{array}{l}\text { Overall } \\
\text { Self-Concept }\end{array}$} & Male & 47 & 187.4468 & 13.09133 & \multirow[t]{2}{*}{86} & \multirow[t]{2}{*}{$3.525^{* *}$} \\
\hline & Female & 41 & 178.9756 & 8.65011 & & \\
\hline \multirow[t]{2}{*}{ Aggression } & Male & 47 & 78.5745 & 19.22605 & \multirow[t]{2}{*}{86} & \multirow[t]{2}{*}{$0.461^{\mathrm{NS}}$} \\
\hline & Female & 41 & 80.4146 & 17.99719 & & \\
\hline
\end{tabular}

$\mathrm{NS}=$ Not significant $\quad * * \mathrm{p} \leq 0.01$ Level of significance 


\section{Self-Concept and Aggression among Institutionalised Orphans of Kashmir}

Table-3 shows an overview of t-values of Self-Concept, its facets and Aggression, with respect to gender of adolescent orphans. It was revealed that male and female adolescent orphans significantly differ on three dimensions of self-concept i.e. physical self-concept, educational self-concept and intellectual self concept. However, no significant difference was found between male and female adolescent orphans in other three self-concept dimensions i.e. social selfconcept, temperamental self-concept and moral self-concept dimensions. It was also revealed that Significant difference exists in the overall self-concept of male and female adolescent orphans ( $\mathrm{t}=3.525)$. Thus, null hypothesis Ho2 (There is no significant difference in the selfconcept of male and female adolescent orphans) stands rejected.

The results of table-3 further reveal that there is no significant difference in the aggression level of male and female adolescent orphans as their obtained t-value of aggression (.461) is insignificant even at 0.05 level. Thus the null hypothesis Ho3 (There is no significant difference in the level of aggression male and female adolescent orphans) stands accepted.

\section{DISCUSSION:}

The present study was undertaken to examine the Self-concept and Aggression among adolescent orphans of Kashmir. After analyzing and interpreting the data it was found that most of these adolescent orphans have above average level of self-concept. The research findings differ from the findings of Aral, Gürsoy and Yıldız Bıçakçı, (2005) who determined that adolescents living in orphanages have low self-concept level. This difference may be attributed to the religious background of these orphanages that help in promoting positive attitude among orphans. This might be further reinforced by the service of mental health professionals which these orphanages organise for the orphans therein from time to time. Thus, working to ensure that these children feel loved and cared for by giving hope for these otherwise hopeless children. Institutionalized pupils high self-concept can also be attributed to the treatment they get from their respective caregivers in these orphanages. As Roeland and Boerma (2004) found out, most institutions or orphanages do not discriminate against orphaned children which boost the orphan's self-concept. As on aggression only $20.45 \%$ have low level of aggression, $42.05 \%$ have moderate level of aggression and $37.5 \%$ have high level of aggression. These findings imply that $79.55 \%$ of sample has moderate to high level of aggression. These research findings are substantiated by the earlier findings of Tizard and Rees (1975) in institutional care children's emotional and behavioural status worsens and even in well run institutions children develop range of negative behaviours, including aggression and indiscriminate affection towards adults. The findings of the present study also reveal that self-concept and its facets have no significant correlation with aggression except for two of its dimensions i.e. temperamental self-concept dimension which has significant negative correlation with aggression and educational self-concept dimension which has significant positive correlation with aggression. These findings differ from the findings of earlier studies (Hay 2000, Garaigordobil et al. 2003, Aral, Gürsoy and Yıldız Bıçakçı, 2005. Estevez, Martinez and Musitu 2006) which show significant negative relationship between self concept and aggression. However, considering the dimension wise aspect of self-concept the findings of 


\section{Self-Concept and Aggression among Institutionalised Orphans of Kashmir}

the present study are in consonance with some of the findings of studies conducted earlier. As in the present study it was found that there is no significant relationship between social self-concept and aggression the similar findings were obtained by Garaigordobil et al. (2003) in study of aggressive interactions and self-concept in a sample of adolescents. Also it was found in the present study that temperamental/emotional self-concept has significant negative relation with aggression similar findings were obtained by Marsh, Parada and Ayotte (2004) in a sample of 903 Canadian students of 7th and 8th grade, that aggressive behavior was significant and negatively related to emotional self concept.

The study further reveals significant difference in the self-concept of male and female adolescent orphans. Male adolescent orphans were found to have higher self-concept than female adolescent orphans. These findings are in agreement with studies by Osborne \& LeGette (1982) and Mboya (1994) who observed higher self-concept among boys than girls in the domains of family, physical, health domains of self-concept and in global self-concept. In aggression no significant difference was found between male and female adolescent orphans. The research findings are in consonance with the study of Moretti and Odgers (2000) who found that when gender specific forms of aggression are considered there is evidence to suggest that girls are as aggressive as boys.

\section{REFERENCES:}

Arnas, Y. A. (2004). Investigation of Self-Concept Level of Children Working in the Streets. Journal of Children and Youth Psychology, 11(1):2-10.

Avdeeva, N. (2009). Development of Self Image in Orphanage Children during the First Three Years of Life. Psychological Science and Education, 3, 13-23.

Avdeeva, N. (2009). Development of Self Image in Orphanage Children during the First Three Years of Life. Psychological Science and Education, 3, 13-23.

Baron, R. A., Richardson, D., 1994. Human Aggression. New York, Plenum Press.

Bilgin, Ş. (2001). Relationship between Anxiety and Self-Respect in Adolescents.

Bowlby J. Maternal care and Mental Health. Geneva, WHO 1961.

Büyüköztürk, Ş. (2003). Data analysis handbook for the social sciences. Pegema Publications, Ankara.

Büyükşahin Çevik, G. (2007). A study on the friend relationships and self esteem of high school 3rd grade students with respect to certain variables. Master's Thesis. Adana: Çukurova University.

Cattell, R.B. 1975, Personality and Motivation Structure and Measurement, New York Harcourt, Brace and World.

Cebe, F. (2005). Comparison of Ego, Respect, Depression, and Anxiety Scores of Children Who Live in Orphanage of Social Service and Child Protection Agency and Those of Children Who Live With Their Family. İstanbul University Institute of Legal Medicine, M.A. Thesis, İstanbul. 


\section{Self-Concept and Aggression among Institutionalised Orphans of Kashmir}

Diaz-Aguado, M. J., Martinez-Arias, R., \& Martin-Seoane, G. (2004). Prevencion de la violencia y la lucha contra la exclusion desde la adolescencia (pp. 21-88) [Violence prevention and struggle against exclusion through adolescence]. Madrid: Instituto de la Juventud. Ministerio de Trabajo y Asuntos Sociales.

Dodge, K. A., Coie, J. D., \& Lynam, D. (2006). Aggression and antisocial behavior in youth. In N. Eisenberg, W. Damon \& R. M. Lerner (Eds.), Handbook of child psychology. Vol. 3. Social, Emotional, and personality development (pp. 719-788). Hoboken, NJ: John Wiley \& Sons.

Estevez, E., Murgui, S., \& Musitu, G. (2008). Psychosocial adjustment in aggressors, pure victims and aggressive victims at school. European Journal of Education and Psychology, 1, 33-44.

Estevez, E., Murgui, S., Musitu, G., \& Moreno, D. (2008a). Adolescent aggression: effects of gender and family and school environments. Journal of Adolescence, 31, 433-450. DOI: 10.1016/j.adolescence.2007.09.007

Estevez, E., Musitu, G., \& Herrero, J. (2005). The influence of violent behavior and victimization at school on psychological distress: the role of parents and teachers. Adolescence, 40, 183-196.

Freud A., A Solint and H. Goldstein 1973. Beyond the best Interest of the Child. London: Andre Deutsch.

Garaigordobil, M., Cruz, S., \& Perez, J. I. (2003). Analisis correlacional y predictivo del autoconcepto con otros factores conductuales, cognitivos y emocionales de la personalidad durante la adolescencia [A correlational and predictive analysis of selfconcept with other behavioral, cognitive and emocional factors of personality during adolescence]. Estudios de Psicologia, 24, 113-134.

Gonzalez-Pienda, J. A., Nuñez, J. C., Gonzalez-Pumariega, S., \& Garcia, M. S. (1997). Autoconcepto, autoestima y aprendizaje escolar [Self-concept, self-esteem and school learning]. Psicothema, 9, 271-289.

Goodwin, D. K. 1994. No ordinary Times, p. 416, Simon and Schuster, N.Y Tizard B and Rees J .The effect of early institutional rearing on behavior problems and affectional relationships of 4 year old children. The Journal of child psychology and psychiatry1975, 16, 61-73.

Hay, I. (2000). Gender self-concept profiles of adolescents suspended from high school. Journal of Child Psychology and Psychiatry, 41, 345-352.

Marcus, R. F. (2007). Aggression and violence in adolescence. Nueva York: Cambridge University Press.

Marsh, H. W., Craven, R. G., \& McInerney, D. M. (2003). International advances in selfresearch. In H. W. Marsh, R. G. Craven \& D. M. McInerney (Eds.), International advances in self research (pp. 3-14). Greenwich, CT: Information Age Publishing.

Marsh, H. W., Parada, R. H., \& Ayotte, V. (2004). A multidimensional perspective of relations between self-concept (Self-Concept Questionnaire II) and adolescent mental health 


\section{Self-Concept and Aggression among Institutionalised Orphans of Kashmir}

(Youth Self-Report). Psychological Assessment, 16, 27-41. DOI: 10.1037/10403590.16.1.27.

Mboya MM 1994. Cross-cultural study of the structure and level of multi-dimensional self concepts in secondary school students. School Psychol. Int. 15: 163-171.

Mccall, J. (1996). Research on the Psychological Effects of Orphanage Care: A Critical Review. Graduate School of Managament, University of California, Irvine.

Osborne WL and LeGette HR. 1982. Sex, race, grade level, and social class differences in selfconcept. Measure. Eval. Guid. 14: 195-201.

Pastor, Y., Balaguer, I., \& Garcia-Merita, M. (2006). Relaciones entre el autoconcepto y el estilo de vida saludable en la adolescencia media: un modelo exploratorio [The relationship between self-concept and a healthy lifestyle in adolescence: an exploratory model]. Psicothema, 18, 18-24.

Roeland M, Boerma JT (2004), Orphanhood and childcare patterns in sub-Saharan Africa: an analysis of national surveys from 40 countries. AIDS vol. 18.

Shavelson, J., Hubner, J. J., \& Stanton, G. C. (1976). Self-concept: validation of construct interpretations. Review of Educational Research, 46, 407-442.

Sloutsky, V.M. (1997). Institutional Care and Developmental Outcomes of 6 and 7 year old Children: A Contextualist Perspective. International Journal of Behavioral Development, 20(1), 131-151.

Üstüner, S., Erol, N. and Şimşek, Z. (2005). Behavioral and Emotional Problems of Children under the Care of Protecting Family. Journal of Child and Youth Psychological Health. 12 (3), 130-140. Bandura, A. Aggression. A social learning analysis. Englewood Cliffs, New Jersey, Prentice Hall.

Verona, E., Javdani, S., \& Sprague, J. (2011). Comparing factor structures of adolescent psychopathology. Psychological Assessment. DOI: 10.1037/a0022055. 